\title{
POSSIBLE IMPACT OF GLOBAL WARMING AND OTHER FACTORS AFFECTING MIGRATION IN RUSSIA WITH EMPHASIS ON SIBERIA
}

\author{
IgOR A. Dets $\odot$ \\ Institute of Geography of the Siberian Branch of the Russian Academy of Sciences, Irkutsk, Russia
}

Manuscript received: July 7, 2020

Revised version: September 7, 2020

\begin{abstract}
Dets I.A., 2020. Possible impact of global warming and other factors affecting migration in Russia with emphasis on Siberia. Quaestiones Geographicae 39(3), Bogucki Wydawnictwo Naukowe, Poznań, pp. 111-123. 2 figs, 1 table.

ABSTRACT: The main issue of the study was to determine the importance of the climate factor for migration flows in Russia, as well as its impact on the intraregional level. The article also discusses the possible prospects that global warming may bring to Siberia. According to the results, the climate factor does not have a crucial influence on the decision to relocate in Russia, but it remains one of the most important, along with economic, social and political factors. At the regional level, the climate factor is less important than the agglomeration factor and others. The impact of global warming has now affected the overall increase in temperatures in Siberia, which is not yet sufficient to generate additional migration flows.
\end{abstract}

KEY WORDS: climate, migration, population change, Russia, Siberia, global warming

*Corresponding author: Igor Dets, igordets@ya.ru

\section{Introduction}

Throughout the history of humankind, climate has undoubtedly played an important role in the development of civilisation. However, the importance of this factor and the extent of its influence on the development of various technologies, trade, culture and other important areas of human activity have been evaluated differently by people. Geographical science has come a long way from geographical determinism to the complete negation of the latter. Researchers finally ended up constructing economic, migratory and other models that assign a secondary role to the climate factor (Piguet et al. 2011). However, the rise of global warming to the forefront of scientific and political debates makes us reconsider the impact of climate on many aspects of human life (Butler 2018).
Migration and population change in various regions of the world are among the most important processes that are significantly affected by climate. The impact is less obvious on relatively regulated international migration, which is mainly directed from regions with more comfortable climates to countries with worse climatic conditions. In territories that do not have strict migration control, the climate can have a much greater impact and even partially smooth out historical and economic factors, as in the case of mass internal migration in the United States (Partridge 2010) and increasing international migration within the EU (Cheshire, Magrini 2006).

At the same time, the influence of climate on migration, which is expressed simultaneously as a push factor (consequences of natural disasters, etc.) and a pull factor (amenity migration for 
better climate conditions), may have different manifestations in terms of time and force of impact (Piguet 2013). Climate as a migration pull factor and a contributor to population change received close attention in the United States in the 1950s, when natural amenities were seen as a motivation for migrants (Ullman 1954). Over the course of decades of research, many papers have been published on environmental demography (Poston, Frisbie 2005), including the relationship between migration and the environment (Hunter, Nawrotzki 2016).

In recent years, the study of the impact of climate as a push factor on population change and the redistribution of migration flows has become one of the most important topics in research in this area (McLeman, Gemenne 2018, Cattaneo et al. 2019). One of the main focuses is on the agricultural industry, which is one of the economic sectors most susceptible to global warming (Dunlap 2010, Falco et al. 2018). However, considerable attention is also being devoted to studying the increased risk of natural disasters affecting population movement, which is most evident in developing countries (Bohra-Mishra et al. 2017), but may have a limited effect in more developed countries (Cameron 2018).

Comprehensive models that calculate the impact of climate conditions on population migration and population change, along with other factors, remain important. The results of such studies (Poston, Zhang 2008, Poston et al. 2009, Rajbhandari, Partridge 2018, Li et al. 2020) suggest that the influence of climate characteristics is significant for migration and population change, even under existing conditions, regardless of the scale and disastrous consequences of global warming, which may increase the impact of this factor.

Due to the diversity of historical, social, linguistic and other conditions, the direct comparison of the influence of climate factors on migration and population change in different countries and territories is a difficult task, which does not always lead to a clear conclusion (Molloy et al. 2011). For some territories, including Russia and especially Siberia, the determining role of climate in the formation of the settlement system and migration flows has never been questioned, but certain features inherent in the Imperial and Socialist periods of Russian history did not allow us to assess the independent role of climate on demographic processes. Active economic incentives to populate the territory of Siberia and the Far East, accompanied by widely used measures of forced relocation, have created a unique situation which has begun to change only in recent decades as the influence of administrative factors has waned.

For example, since 1989, the population of the Chukotka Autonomous District - the most north-eastern territory of Russia - has decreased from 157,000 to less than 51,000 in 2019, and in the Magadan region from 385,000 to 140,000 over the same period. Conversely, an increase in the number of residents from $4,680,000$ to $5,678,000$ was observed in the Krasnodar region - the warmest region in the country. At the same time, the population of Moscow has grown from 8,967,000 in 1989 to $12,692,000$ in 2019, with the population of Moscow region increasing by an additional 1,000,000 people (Regions 2020).

Given the fact that the climate in Moscow is not the most agreeable and warm in the country (the average annual temperature in the city over the past 10 years was $+6.7^{\circ} \mathrm{C}$, whereas the lowest in the country was in Oymyakon $-14.1^{\circ} \mathrm{C}$, and the highest was in Sochi $+15.3^{\circ} \mathrm{C}$ ), the economic factor of migration is contrasted with the climate, although not to the same extent as in Soviet times.

The historical past of the country is an obvious reason for considering the political factor as one of the key determining forces of migration flows in Russia, which many studies mention along with climate characteristics. PostSoviet studies have highlighted the influence of the command and administrative system in the formation of migration flows, especially in the Northern and Eastern regions of Russia. These areas experienced a massive outflow of residents, caused by the elimination of the Soviet system of compensation for those living in remote areas with severe climatic conditions (Soboleva, Melnikov 1999). Later works also emphasised the role of eliminating the planned economic system, which led to a mass closure of enterprises and a subsequent outflow of population from territories plunged into economic depression. They categorised both the collapse of the USSR and the local military conflicts that followed it as political factors that provoked the mass relocation of residents of former Soviet republics (Taskayeva 2007, Nemeryuk, Anikin 
2014). Some researchers consider the political factor to be decisive even in the post-Soviet period of Russian history (Prokhorov, Epstein 2016), whereas others are inclined to argue that economic factors (weak involvement of the local population in the implementation of mining projects and others) prevail today even in the most remote territories with extremely unfavourable climates (Krasnoshtanova 2019).

More detailed studies on an inter-regional level show that climate conditions have a significant impact as a pull factor on migration in Russia, especially at retirement age. Many residents of Siberia are planning to move to warmer areas - they buy apartments, land or houses in advance, and move to a new place of residence after retirement, which even leads to forming a second age peak of migration activity (atypical in other countries) (Karachurina, Mkrtchyan 2017). However, there is currently no analysis of the relationship between climate conditions and population changes in the harsh conditions of Siberia in the broad scientific literature, especially at the level of municipalities (which is rarely researched globally). There is also no analysis of the expected consequences of global warming for the migration dynamics of this territory.

\section{Materials and methods}

\section{Limitations of data available for analysis}

The main statistical data used is from Rosstat, the Russian State Statistical Agency. Demographic statistics of the Agency have some drawbacks. Migration data is collected based on the official registration of citizens at their place of residence. However, many apartment proprietors do not register tenants living in their property, as this grants tenants certain rights and imposes significant restrictions on the property owner. Furthermore, the obligation of the proprietor to register tenants is not strictly enforced. As a result, most tenants agree to live in other cities and regions while officially registered in their hometown. For this reason, migrants do not expect to receive a full range of medical, educational and other social services, and their voting rights in local and regional elections are restricted. Errors in migration statistics are usually corrected after conducting all-Russian population censuses, which take into account only the actual location of citizens (the next regular census has been postponed due to the COVID-19 pandemic and is scheduled for spring 2021). Different demographic data are also not released at the same time, which made it impossible to use 2019 data for the analysis at the interregional level, being limited to the time period 2010-2018.

Statistics at the municipal level are also fragmentary due to numerous indicators, one of them being the lack of method uniformity in different regions, which limits the choice of data for analysis. Meteorological data in Russia also has its limitations. For example, the network of meteorological stations is not regularly spread, thus does not provide the necessary data density for research at municipal level, as assumptions must be made when extrapolating data to nearby territories.

Wind speed and relative humidity indicators, often analysed in various methods (Piguet 2010), were not used as likely factors affecting population migration and changes in its population as there is only a small range of values in the regions of the main settlement band (wind speed 2-5 metres per second and three allocated zones with significantly different relative humidity). At the same time, the average wind speed and relative humidity are milder in regions with less favourable climatic conditions. Thus, in Central and Eastern Siberia, where the winters are the coldest, due to the Asian winter anticyclone, winds rarely exceed 1-3 metres per second, and the relative humidity of the air due to limited access of oceanic air masses in winter and weak evaporation is kept at about $70 \%$. An important limitation is that at the municipal level, these parameters are not provided by the meteorological services in the form required for analysis.

\section{Materials used at the interregional level}

Based on these circumstances, in this study, we decided to view the relationship of climate factors with migration dynamics through different indicators at the interregional and municipal levels.

To determine the relationship between climate factors and migration dynamics at the interregional level, we used Rosstat annual data on 
migration growth of the population per 10,000 people in 2010-2018 (Regions 2020) and data on the average temperature of July and January of the Russian Federal Hydrometeorological Center (Roshydromet) (Environment 2020). Conducting a correlation analysis for two different months at the interregional level was particularly important because of the greater temperature variation between regions in winter conditions (the temperature range is $16^{\circ} \mathrm{C}$ in July and $-37.1^{\circ} \mathrm{C}$ in January).

The correlation analysis of the relationship between migration and the gross regional product was carried out on the basis of Rosstat data for 2010 (Gross 2020).

\section{Materials used at the municipal level}

At the level of municipal territories, represented by the example of Eastern Siberia (Krasnoyarsk region, Irkutsk region, Zabaykalsky region, Republic of Buryatia, Republic of Tuva, Republic of Khakassia), the relationship between factors was estimated based on population change in 2010-2019. Calculations were made from Rosstat data (Indicators 2020) and data on average annual temperature over the past 10 years, gathered from the international exchange of actual weather data provided by the National oceanic and atmospheric administration to the web service rp5.ru (Weather 2020). The average annual temperature for a number of municipal territories was based on the indicators of the nearest weather station, which is often located in a neighbouring municipal area with similar geographical conditions.
The choice of the average annual temperature at the municipal level as the main parameter is due not only to the limited amount of data on monthly statistics but also to the special importance of average annual temperatures for Siberian conditions. Huge areas of permafrost are common due to low average annual temperatures, but due to global warming, temperatures in these areas are increasing and already exceed $0^{\circ} \mathrm{C}$. Further warming threatens the functioning of transport, utilities, energy and other life-supporting infrastructure, which will need constant reconstruction and modernisation as permafrost melts.

\section{Results and discussion}

\section{Climate, economic and political factors - counteraction and combination}

The results of the correlation analysis show a low level of dependence of interregional migration flows on average temperatures in the regions. The average July temperature correlates with migration data in the range from $r=0.03$ to $r=0.3$ (with an average of $r=0.2$ ) with a clear increase during the economic crisis of 2014-2016 (Table 1). Indicators are higher when assessing the relationship between migration and January average temperatures, which suggests a greater influence of cold winters on people's desire to leave. However, these indicators are not high enough and vary from $r=0.23$ to $r=0.43$ (with an average of $r=0.36$ ).

Table 1. Indicators of correlation of the migration growth coefficient by regions of Russia (in \%o) and other data under consideration.

\begin{tabular}{|c|c|c|c|c|c|c|c|c|c|}
\hline & \multicolumn{9}{|c|}{ Years } \\
\hline & 2010 & 2011 & 2012 & 2013 & 2014 & 2015 & 2016 & 2017 & 2018 \\
\hline \multicolumn{10}{|c|}{ Migration and average temperature } \\
\hline in January & 0.37 & 0.23 & 0.27 & 0.38 & 0.41 & 0.43 & 0.41 & 0.40 & 0.33 \\
\hline in July & 0.26 & 0.03 & 0.11 & 0.23 & 0.29 & 0.30 & 0.30 & 0.19 & 0.12 \\
\hline \multicolumn{10}{|c|}{ Migration and average temperature (without specified regions)* } \\
\hline in January & 0.49 & 0.32 & 0.42 & 0.53 & 0.55 & 0.57 & 0.56 & 0.54 & 0.46 \\
\hline in July & 0.40 & 0.06 & 0.21 & 0.33 & 0.39 & 0.39 & 0.39 & 0.28 & 0.19 \\
\hline \multicolumn{10}{|c|}{ Migration and gross regional product in 2010} \\
\hline & 0.47 & 0.34 & 0.41 & 0.37 & 0.38 & 0.37 & 0.37 & 0.39 & 0.39 \\
\hline \multicolumn{10}{|c|}{ Migration and gross regional product per capita in 2010} \\
\hline & 0.03 & 0.23 & 0.18 & 0.15 & 0.04 & 0.11 & 0.08 & 0.21 & 0.28 \\
\hline
\end{tabular}

*Republics excluded: Altai, Buryatia, Chechnya, Dagestan, Ingushetia, Kabardino-Balkaria, Kalmykia, KarachayCherkessia, North Ossetia, Tyva and Yakutia. 
These low results are nevertheless comparable to the indicators of the relationship between migration and economic indicators. Thus, gross regional product (GRP) correlates with migration data in the range from $r=0.34$ to $r=0.47$ (with an average of $r=0.39$ ). It is important to note that during the period of economic deterioration (2013-2017), the relationship between migration and the climate factor increases and exceeds the relationship with GRP. This analysis also shows that the volume of the regional economy is much more important for migration than the per capita regional product. It is obvious that migrants are more often aware of the level of economic development of the region, rather than how this wealth is distributed to the number of its residents. The same can be assumed about the awareness of migrants about the temperature difference between regions - people know perfectly well that the climate on the Black Sea coast is the best in Russia, but they do not know much about the temperature difference between Novosibirsk (Western Siberia) and Voronezh (European Russia), for example.

The result of the correlation and regression analysis for 2015 alone (the first year after the change of the status of the Crimean Peninsula) is shown in graphic form in Figure 1. It allows us to identify the regions that deviate most from the line of the assumed relationship between average January temperatures and the migration growth rate. On the chart, we see that below the trend line are mostly territories with worse economic indicators, i.e. the outflow of population is even greater than could be explained by the low winter temperatures. These territories include not only regions in the East of the country, such as the Chukotka Autonomous District, the Magadan region and the Jewish Autonomous region, but also regions that lag behind in economic development in European Russia, such as the Komi Republic. One of the few exceptions at the bottom of the chart is the Yamalo-Nenets Autonomous District, whose economic indicators are among the best in the country and are attributed to the intensive development of natural gas extraction. The discrepancy in economic and migration indicators can be explained by the fact that in the extremely harsh climate of the territory, the work of almost all enterprises is organised on a month-long shift basis, which leads to the fact that the permanent population of the district $(544,000$ in 2020) gradually leaves the territory.

At the top of the chart are regions with much higher migration attractiveness than the expected effect of climate factors could provide. In addition to Moscow and the Moscow region, the Krasnoyarsk region and Novosibirsk region, as well as the Tyumen region, have a higher

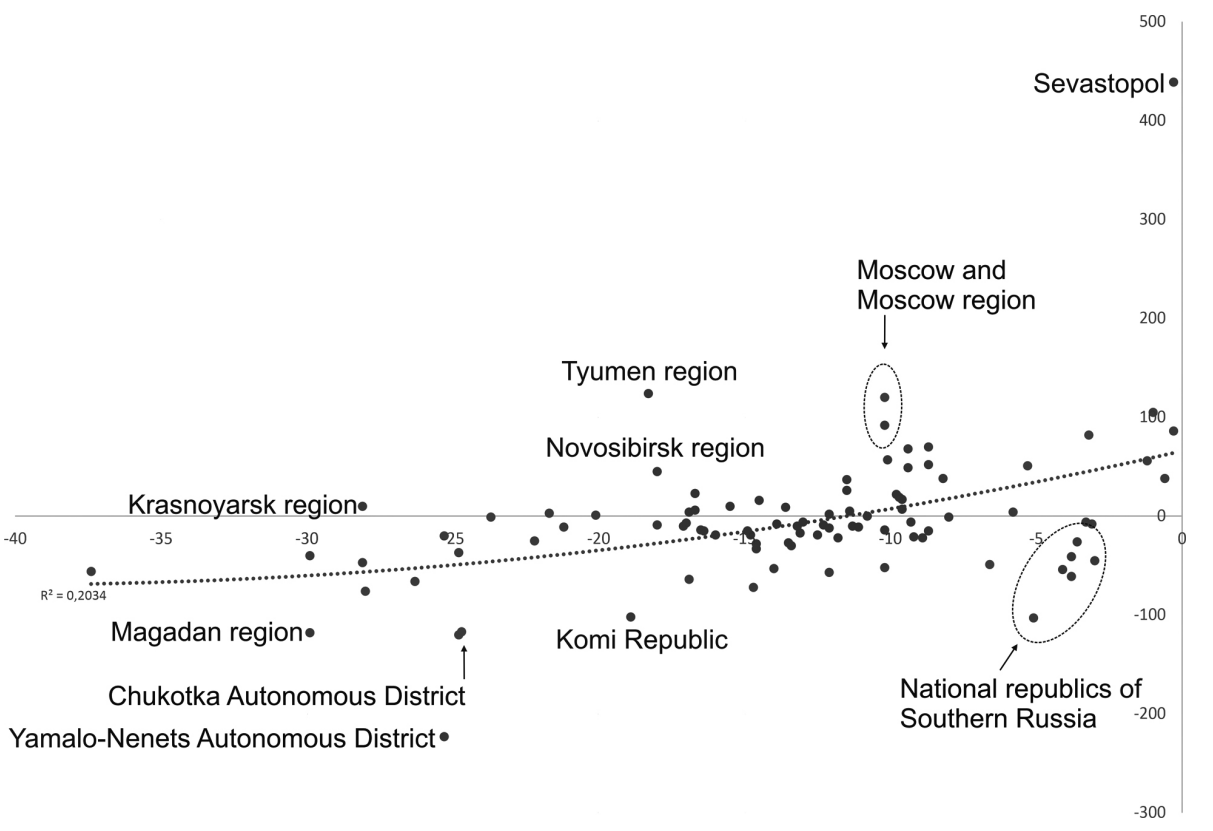

Fig. 1. Average January temperature $\left({ }^{\circ} \mathrm{C}\right)$ according to climatic norm (horizontal scale) and population migration (per 10,000 people) in the regions of Russia in 2015 (vertical scale). 
migration inflow. At the same time, the inflow in the Krasnoyarsk region and the Novosibirsk region is only partly due to positive economic indicators. Most importantly, these areas act as a stepping stone in migration, i.e. as alternatives to Moscow (or rather preceding it), attracting residents of Siberia and the Russian Far East. In the case of the Tyumen region (namely its southern part), the area is in fact the centre of development for the oil and gas resources of the KhantyMansi Autonomous District and Yamalo-Nenets Autonomous District, located in even more severe climatic conditions.

The graph also highlights the role of the political factors for migration. Sevastopol, which in 2015 Rosstat began to classify as a region of Russia (as part of the Crimean Peninsula), experienced a surge in migration (then gradually decreased), leaving other climate-attractive regions such as Krasnodar region far behind. The Russians who moved to Crimea and Sevastopol were motivated not only by the demonstration of Russia's political ambitions but also by prerequisites that are more practical - massive infrastructure construction began and wide opportunities for employment and business opened up in the resort region known since the days of the Russian Empire (Tsoy 2019).

The regional level did not display the exceptional role of the climate factor either (Figure 2). Indeed, for those who seek to move to places with more favourable climatic conditions, moving even from the coldest places in Eastern Siberia to the warmest can give no more than $10^{\circ} \mathrm{C}$ difference in the average annual temperature, while even moving to Moscow with an average annual temperature of $+6.7^{\circ} \mathrm{C}$ will make more sense (for example, the average annual temperature in Krasnoyarsk was only $+2{ }^{\circ} \mathrm{C}$ in the last 10 years). All the more unattractive are the warmest territories of Eastern Siberia in comparison with the South of Russia and, in particular, the Black Sea coast. In such circumstances, it is quite understandable that migrants do not choose the warmest areas of Eastern Siberia, many of which are currently economically depressed rural areas experiencing long-term depopulation.

In fact, this map not only shows the effect of the climate factor at the regional level but also illustrates the importance of economic factor very clearly. In the Far North, the world's northernmost city with a population of more than 150,000

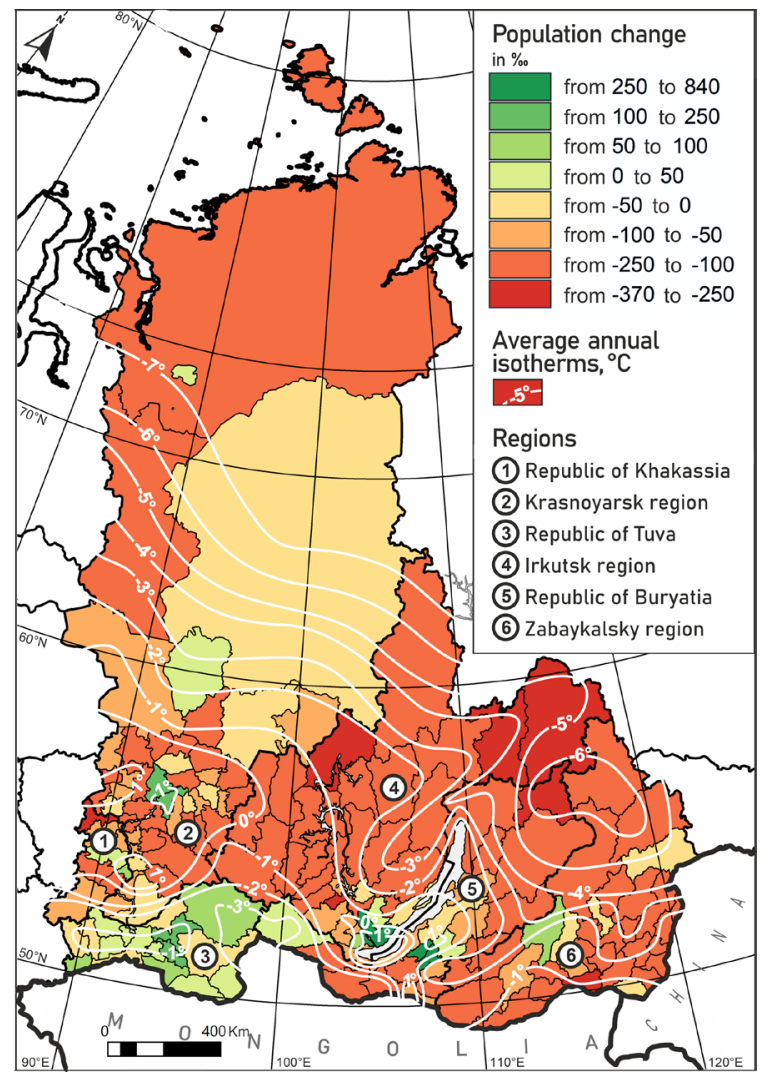

Fig. 2. Population change in $2010-2019$ per 1,000 people and the average annual temperature in municipalities of the East Siberian economic district (temperatures are shown only in the range from $-7^{\circ} \mathrm{C}$ to $+1^{\circ} \mathrm{C}$, in mountainous areas may differ significantly from those indicated).

people is located in the difficult conditions of the subarctic climate. The city of Norilsk, marked in green on this map, has increased population by more than 5,000 people to 180,000 over the past 10 years, which obviously was not caused by the average annual temperature increase of $2^{\circ} \mathrm{C}$ in the past 10 years alone. Only high incomes resulting from copper-nickel production are able to keep such a large population in a city where the polar night lasts for a month and a half, and snow cover persists for 7.5-9 months a year. Migration growth is also formed in some other municipal territories where minerals are extracted. However, in modern Russia, the development of new deposits no longer involves the construction of new permanent settlements or cities with large populations like Norilsk (Dets 2018). Gold mining and other similar sectors of the economy generate positive migration growth usually for territories with a small population. The main reason is that, in the post-Soviet period, 
the shift method of work on mining operations is almost universal, which leads to the formation of temporary settlements that are liquidated at the completion of production.

\section{When economic opportunities are more important - agglomeration factor at the regional scale}

In some parts of the area under review, climate indicators differ significantly and due to the presence of mountain territories do not depend directly on the latitude of the location. However, at this level, the correlation and regression analysis did not show a sufficiently high relationship between temperature indicators, net migration or migration per 1,000 population. At this level, regional migration flows are much more likely to be attracted by regional capitals, which in some cases are located far from the warmest climatic conditions (for example, Chita - the centre of Zabaykalsky region, Kyzyl - the centre of the Republic of Tuva, etc.).

Consideration of the regional examples separately, allowing us to take into account the importance of regional centres as migration hubs, at points may demonstrate comparable correlation indicators of relationships with all-Russian ones. However, the highest values of this dependance are found in regions where the administrative centre is located in the most favourable climatic conditions. Thus, in the Republic of Khakassia, the strength of the correlation between net migration and average annual temperature ranged from $r=$ 0.37 to $r=0.6$, and the correlation with migration per 1,000 people in 2010-2018 was $r=0.8$.

However, a comparison of the latter indicator with other regions, such as the Republic of Buryatia $(r=0.28)$, Krasnoyarsk region $(r=0.31)$ and the Irkutsk region $(r=0.42)$, as well as examples of the Republic of Tyva $(r=0.14)$ and the Zabaykalsky region $(r=0.01)$, does not confirm the leading role of the climatic factor at the regional level.

At the same time, using the example of the Irkutsk region, it can be stated that a combination of economic, agglomeration and climate factors can provide very strong advantages at the regional level. Located in the southernmost part of the region, Irkutsk attracts migrants who have increased the population of the agglomeration by more than $20 \%$ over the past decade to $1,100,000$ people (Bogdanov et al. 2019). An example is also the catastrophic flooding of 2019 in the northwest of the region, the causes and consequences of which have not yet been fully studied by scientists. Many flood-affected residents of Tulun (population 41,000, average annual temperature about $-0.1^{\circ} \mathrm{C}$ ), according to media reports (Vasilev 2019, Bobrova 2020), decided to move to Bratsk (distance $240 \mathrm{~km}$, population 226,000, average annual temperature about $-0.1^{\circ} \mathrm{C}$ ) or Irkutsk (distance $400 \mathrm{~km}$, population 624,000, average annual temperature $1.2^{\circ} \mathrm{C}$ ), despite the offer to move to new housing in their city. Migrants' relocating from the north to the largest cities in these regions is also often a compromise between the desire to live in a warmer place and the reluctance to move too far from their native places or leave Siberia forever.

\section{Effect of additional factors in national republics}

One of the outcomes of the study was the obvious deviation of the results of the national republics - the types of regions historically defined as ones with the large share of ethnic population - from the rest of the regions. The indicators of the national republics of the South of Russia form a separate cluster on the graph (see Figure 1): Chechnya, Dagestan, Ingushetia, KabardinoBalkaria, Kalmykia, Karachay-Cherkessia and North Ossetia. These regions are located in an area close to the most favourable climatic conditions available in Russia.

The territories inhabited by indigenous peoples in Siberia are in a special demographic situation as well, as we can see it on the map (see Figure 2). Such peoples as the Tuvans and Buryats still have a higher birth rate than the average in Russia, which creates conditions for natural population growth in the territories where they reside compactly or prevail in number. At the same time, the majority of these indigenous peoples live in territories with more severe climatic conditions, often due to the mountainous nature of the terrain. This is especially noticeable in the case of the Republic of Tuva, located in the mountains of southern Siberia, where average annual temperatures are significantly lower than that in the more northern territories of Central Siberia. 
A separate analysis of the relationship between the climate factor and migration processes was conducted to understand the impact of additional factors affecting migration (see Table 1 ). For this purpose, the additional analysis excluded the republics whose population has pronounced features in population reproduction and migration strategies, which particularly reflects the positive indicator of natural population growth throughout the study period (in contrast to other regions of Russia). The prevailing demographic features of the Altai, Buryatia, Chechnya, Dagestan, Ingushetia, Kabardino-Balkaria, Kalmykia, Karachay-Cherkessia, North Ossetia, Tyva and Yakutia republics are due to various reasons: a high percentage of the rural population, a low share of ethnic Russians in the population (in most of them it does not exceed a third), a peripheral position relative to the main settlement belt of Russia, a comparatively short stay within the country's borders and the peculiarities of national culture or religion (Tikhomirov, Tikhomirova 2020). This way, excluding these regions from the analysis leads to an increase in the correlation index (range from $r=0.32$ to $r=$ 0.57) (see Table 1).

Thus, the influence of additional factors leads to distortions in the migration balance of these national republics. Often, economic conditions do not contribute to the migratory attractiveness of indigenous peoples' territories, as they have lower rates of economic and social development, underdeveloped industry and higher unemployment rates (Popod'ko 2017). At the same time, the indigenous population of such territories is also concentrated in regional capitals (Kyzyl in the Republic of Tuva, Ulan-Ude in the Republic of Buryatia, etc.) and nearby municipalities, but much less often decides to move to other regions of Russia, including Moscow. A number of factors motivate this self-restriction of migration: ethnic, cultural, religious and even linguistic. The latter is also most noticeable in the Republic of Tuva, where the Russian-speaking population has significantly decreased after the collapse of the Soviet Union (from $32.0 \%$ in 1989 to $16.3 \%$ in 2010 according to census data). In some municipal areas of the Republic, the Russian language has almost disappeared from everyday life, and there are practically no native speakers, which leads to poor mastery of the Russian language.
For this reason, even educational migration becomes almost impossible for residents of such territories, whereas this is very common among school graduates in Russia who seek to study at universities in Moscow, St. Petersburg or at least Novosibirsk, Tomsk or Krasnoyarsk.

Religious and cultural factors also have some impact on the migration of indigenous peoples. It can be assumed that some residents of regions with a predominantly Muslim population (many of which are located in the North Caucasus) do not consider it possible for themselves to move to other Russian regions due to their unwillingness to abandon traditional clothing or religious rituals. Even if Buddhism, which is widespread on the territory of the study only in three Republics (Buryatia, Kalmykia and Tuva), generally does not require followers to make noticeable differences in clothing or daily practices, it is the existing cultural characteristics and sense of native land that are important factors for retaining many potential migrants.

Eventually, indigenous representatives of some national republics migrate mainly within their regions and do not seek to move to other regions of Russia due to differing religious, cultural or social practices, and in some cases due to poor knowledge of the Russian language or fear of encountering manifestations of ethnic hostility. At the same time, in such national republics, a very different cultural environment creates an obstacle for migrants from other Russian regions, and residents who do not belong to the nation-centred community often move outside of the region. All these circumstances significantly correct the effect of the climate factor in Russia.

\section{Climatic factor in the era of global warming - catastrophic consequences and some possible positive effects of warming on Siberian territories}

Consideration of the climatic factor becomes especially relevant during the period of global warming, which becomes the cause of many processes that will have a direct or indirect impact on migration flows in Siberia in the future.

Warming, which over the past 30 years has been more than $2^{\circ} \mathrm{C}$ for Russia, in some parts of Siberia was even more noticeable (Russian 2019). It is also assumed that in the future, 
Siberia, especially its arctic part, will continue to see increase in average temperatures at an accelerated pace. These circumstances are of particular concern to researchers, most often in the context of the release of huge reserves of methane (Shakhova et al. 2019, Masyagina, Menyailo 2020), which is an even more dangerous greenhouse gas that can repeatedly accelerate global warming.

For Siberia, more frequent flooding may be another important consequence of global warming (Kichigina 2020). However, the increased number of recorded floods can be caused not only by a slightly increased amount of precipitation in recent decades but also by active deforestation (Bradshaw et al. 2007), which is massively carried out in the region by both large timber industry complexes and illegal loggers. It is likely that the Siberian forests in the future will suffer even more from the increased amount of fires, the dependence on which is scientifically observed for growth in temperature (Ponomarev et al. 2016). Meanwhile, if floods cause damage to specific localities or individual territories (not only in the North, but also in the relatively densely populated south), then air pollution caused by fires affects residents of vast territories, including the largest cities in the region.

Though many researchers consider the processes of global warming as extremely negative (Mueller et al. 2016), we must recognise that in the regional context, some of its side effects can be regarded positively. One of the consequences of warming is the free passage of the Northern sea route, which the Russian government hopes to use for its own shortly, and controlled transit cargo traffic (Didenko, Cherenkov 2018).

There are also research results that show the possibility of other positive effects of warming on Siberian territories (Tchebakova et al. 2011). The increase in the area suitable for the growth of many agricultural crops can lead to the fact that Siberia will become one of the main suppliers of food in the Russian and world markets. For more than a century, agriculture in the south of Western Siberia has shown sufficient productivity and profitability, and the most climate-friendly Altai region has already become one of the main agricultural areas of the country. Warming is also likely to shift the Northern edge of the forest closer to the Arctic Ocean, which may smooth out some environmental problems and increase the economic base of the now remote and uninhabited territories.

\section{What global warming can change in migration in Siberia}

Indeed, the migration process within Russia cannot be explained by only one major factor; however, the climate certainly does contribute. Siberia, which has been losing population for the past 30 years, may currently be one of the few territories of the world where climate migration is so widespread, due to the deliberate mass settlement of climatically unfavourable areas during the Soviet period. Nevertheless, Siberia does not remain separate from global processes, so can global warming provoke a new type of climate migration in the region, which is mainly associated with global warming and is estimated to reach up to 1 billion people by 2050? (Bassetti 2019).

The destruction of permafrost itself, or the resulting carbon dioxide and methane emissions, can only affect migration processes in Siberia on a limited scale. The current permafrost distribution covers huge areas in Siberia, but most of this territory is very sparsely populated. Undeniably, for a particular settlement, the consequences of the destruction of infrastructure and housing can be disastrous, as well as problems for the local traditional economy associated with the rivers or taiga (Hiyama, Takakura 2018), but the number of such settlements and their population is limited, even on a regional scale. The negative consequences of climate change in this case may result in accelerated migration of the population to regional centres, which themselves in most cases are located outside the permafrost zone or in areas of its island distribution.

Indeed, serious difficulties may arise for infrastructure in major cities in the North of Siberia, which are small in number; on the territory of our study these include, most importantly, Norilsk (Shiklomanov et al. 2017). The migration consequences for such cities can actually be presented in two ways: the preservation of the population with expensive infrastructure reconstruction measures or a sharp migration outflow with the slow destruction of the urban economy. The real fate of these cities will be determined by the profitability of industrial production located there, as after the 
collapse of the Soviet Union, the government of the country began to spend much less on maintaining the population in the northern regions and in Siberia, which was previously justified mainly by geopolitical considerations. In the event of the depletion of Norilsk ore reserves or a long-term decline in prices for the plant's products, we can expect a sharp decline in population. Notably, people will most likely move not to the warmer territories of Siberia, but to the European part of the country; many residents tend to buy housing in warmer regions in advance (Laruelle 2016).

The migration response to natural disasters will also be different: as in the case of floods, it can be assumed that disasters in limited areas will increase regional centripetal trends, whereas disasters in the form of forest fires in uninhabited areas may not lead to changes in demographic processes.

At the same time, the development of Northern Sea Route is capable of positively influencing the migration processes in the Arctic part of Russia to some extent. This is not to say that this circumstance can make life on the cold Arctic coast of Siberia more attractive, but easing the supply of the population of the far North can reduce the migration outflow from the territory to some extent (Fedorov et al. 2020). Less cold winters also result in savings on heating buildings, but this will affect production costs rather than significantly saving household expenses and affect their migration strategies.

Siberia's enlarged agro-climatic resources may not be an important advantage for migrants in the future. The growth of the forests suitable for economic use in the area may not necessarily be viewed as such advantage either. It is also hard to say that the projected climate warming will lead to the average annual temperatures of Krasnoyarsk or Irkutsk being equal to Moscow or even more so to Sochi. At the same time it is not necessary to discount the power of myths, images of territories and self-identification of migrants - all of this largely forms migration flows (Zamyatina 2017). In particular, the position of the media will determine how attractive Siberia will look in the eyes of possible migrants.

However, more important for this prediction will be not only the consequences of global warming in Siberia but also its consequences for other more populated areas. Will living conditions in the European part of the country or in Central Asia or China become much more difficult than they are now? Will the future climate of Siberia be more attractive for residents of these territories than it is now? Moreover, will the Russian Government encourage or discourage migration to Siberia?

None of these questions have a simple answer. However, we can already assume that certain territories in Siberia have some chances of being attractive to migrants in the future. This is especially possible for territories that are already in the zone of positive average annual temperatures, which suggests that the entire infrastructure located there will not require adaptation, as it does not depend on the process of melting permafrost (even before the beginning of the intensive process of global warming, permafrost had a predominantly fragmentary distribution in these territories).

It is also quite likely that possible future migration will be directed primarily to the most developed economic centres. This is mainly Krasnoyarsk, which has more than a million inhabitants, and to some extent Irkutsk. Measures to economically stimulate the development of suburban areas of these cities, allowing them to expand the influence of their agglomeration effects, could already alleviate the impact on the environment, as well as improve the quality of life in these territories, which are rapidly increasing their population at present (which also is reflected in Fig. 2). Perhaps these measures could also mitigate the consequences of a possible increase in migration flows to Siberia, including the problems of inter-ethnic and inter-religious interaction that are already being detected in major centres (Kolesnik et al. 2016).

\section{Conclusions}

The study analyses data from Rosstat on migration growth and population change in recent years and data from the Roshydromet on average temperatures in Russian regions, as well as considers weather archives over the past 10 years in municipalities of the East Siberian economic district. Data on gross regional product and gross regional product per capita were also evaluated as auxiliary data. 
The assessment of the relationship between climate and migration flows, as well as the overall change in population, was based on data on the average annual temperatures of January and July at the country level and data on average annual temperatures at the intraregional level.

Despite the undeniable role of climate in the historical patterns of settlement of the territory of Russia, the results of the study did not reveal that climate factors play a decisive role in the formation of migration flows at either national or regional levels.

At the same time, the uneven Russian economic space weakens the strength of the climate factor. Nevertheless, despite the general economic underdevelopment, the most climate-friendly regions of Southern Russia continue to actively attract migrants to their territory.

Analysis at the regional level, conducted on the example of a number of Siberian regions, showed that the climate factor influences population change in combination with agglomeration, ethnical and other factors. In part, this result may be due to the possibility of freely moving to much more climatically mild regions in the European part of Russia.

Additionally, for migrants seeking economic benefits from relocation, the administrative centre of their region continues to play a primary role as a stepping-stone for further movement to Moscow directly or via Krasnoyarsk or Novosibirsk.

The question of whether global warming will make Siberian territories more appealing for migrants remains open. The increased temperatures over the past decades have not yet led to a drastic climate mitigation in Siberia, but some forecasts show that the territories under consideration may become much more attractive, at least for the development of agriculture. It is not yet possible to predict the impact of global warming on the increase in the number and strength of catastrophic natural phenomena not only in Siberia but also in the European part of Russia, Central Asia, or China, which under certain conditions may become a source of migration flows heading to Siberia. However, it is already possible to assume that the main centres of attraction for such migrants would be the largest urban agglomerations experiencing an influx of population due to the internal resources of Siberia and the Russian
Far East at present. Some attention by the Federal Government to these agglomerations could smooth out the existing and potential environmental and social difficulties of these territories.

If the prospect of global warming calls into question the existence of the entire established order of things around the world, it could dramatically change the appeal of Siberian territory for migrants in the not-so-distant future.

\section{Acknowledgements}

This work was supported by the Institute of Geography SB RAS (state assignment's registration number AAAA-A19-119122490007-4) and Russian Foundation for Basic Research, Government of Krasnoyarsk Territory, Krasnoyarsk Regional Fund of Science (grant number 1945-240004), namely 'Predictions of the ecological-economic potential for possible "climatic" migrations in the Angara-Yenisei macroregion in a changing climate of the 21st century'. I also thank the reviewers for their comments and advice.

\section{References}

Bassetti F., 2019. Environmental migrants: up to 1 billion by 2050. Foresight. Online: climateforesight.eu/migrations/ environmental-migrants-up-to-1-billion-by-2050/ (accessed 14 May 2020).

Bobrova I., 2020. Despite Putin's efforts, Tulun has become a ghost town. Moskovsky Komsomolets. Online: mk.ru/ social/2020/01/04/nesmotrya-na-usiliya-putina-tulun-stal-gorodomprizrakom.html (accessed 3 April 2020).

Bogdanov V.N., Korytny L.M., Emelyanova N.V., Antipina U.V., 2019. Sotsial'no-ekologicheskiye osobennosti suburbanizatsii v Irkutskoy aglomeratsii (Socio-ecological characteristics of suburbanization in the Irkutsk agglomeration). Ecology of Urban Areas 3: 28-33. DOI 10.24411/1816-1863-2019-13028

Bohra-Mishra P., Oppenheimer M., Cai R., Feng S., Licker R., 2017. Climate variability and migration in the Philippines. Population and Environment 38: 286-308. DOI 10.1007/s11111-016-0263-x

Bradshaw C.J.A., Sodhi N.S., Peh K.S.-H., Brook B.W., 2007. Global evidence that deforestation amplifies flood risk and severity in the developing world. Global Change Biology 13: 2379-2395. DOI 10.1111/j.1365-2486.2007.01446.x

Butler C.D., 2018. Climate change, health and existential risks to civilization: A comprehensive review (1989-2013). International Journal of Environmental Research and Public Health 15(10): 2266. DOI 10.3390/ijerph15102266

Cameron M.P., 2018. Climate change, internal migration, and the future spatial distribution of population: A case study of New Zealand. Population and Environment 39: 239-260. DOI 10.1007/s11111-017-0289-8 
Cattaneo C., Beine M., Fröhlich C.J., Kniveton D., Martinez-Zarzoso I., Mastrorillo M., Millock K., Piguet E., Schraven, B., 2019. Human migration in the era of climate change. Review of Environmental Economics and Policy 13(2): 189-206. DOI 10.1093/reep/rez008

Cheshire P.C., Magrini S., 2006. Population growth in European cities: Weather matters - but only nationally. Regional Studies 40: 23-37. DOI 10.1080/00343400500449259

Dets I.A., 2018. Proyektnyy podkhod v territorial'nom razvitii: Baykal'skiy region (Project approach in territorial development: Baikal region). Academic publishing house "Geo.", Novosibirsk. DOI 10.21782/B978-5-6041445-0-3

Didenko N.I., Cherenkov V.I., 2018. Economic and geopolitical aspects of developing the Northern Sea Route. IOP Conference Series: Earth and Environmental Science 180: 012012. doi: 10.1088/1755-1315/180/1/012012

Dunlap R.E., 2010. Climate change and rural sociology: Broadening the research agenda. Rural Sociology 75: 1727. DOI 10.1111/j.1549-0831.2009.00010.x

Environment. Climate change. Average monthly air temperature, 2020. Roshydromet Russia Federal Hydrometeorological Center. Online: gks.ru/folder/11194 (accessed 21 May 2020).

Falco C., Donzelli F., Olper A., 2018. Climate change, agriculture and migration: A survey. Sustainability 10: 1405. DOI $10.3390 /$ su10051405

Fedorov V.P., Zhuravel V.P., Grinyaev S.N., Medvedev, D.A. (2020, January). The northern sea route: Problems and prospects of development of transport route in the Arctic. IOP Conference Series: Earth and Environmental Science 434: 012007. DOI 10.1088/1755-1315/434/1/012007

Gross regional product. Gross regional product per capita, 2020. Rosstat Russian State Statistics Agency. Online: gks.ru/ bgd/regl/B12_14p/Main.htm (accessed 15 April 2020).

Hiyama T., Takakura H. (Eds.), 2018. Global warming and human - nature dimension in Northern Eurasia. Global environmental studies, Springer Singapore, Singapore. DOI 10.1007/978-981-10-4648-3

Hunter L.M., Nawrotzki R., 2016. Migration and the environment. In: White M.J. (ed.), International handbook of migration and population distribution. Springer Netherlands, Dordrecht: 465-484. DOI 10.1007/978-94-017-7282-2_21

Indicators of municipalities, 2020. Rosstat Russian State Statistics Agency. Online: gks.ru/free_doc/new_site/bd_ munst/munst.htm (accessed 12 April 2020).

Karachurina L.B., Mkrtchyan N.V., 2017. Vozrastnyye osobennosti mezhregional'noy migratsii naseleniya $\mathrm{v}$ Rossii (Age specific of interregional migration in Russia). Region: Economics and Sociology 4(96): 101-125. DOI 10.15372/REG20170405

Kichigina N., 2020. Geographical analysis of river flood hazard in Siberia. International Journal of River Basin Management 18(2): 1-10. DOI 10.1080/15715124.2020.1742136

Kolesnik M.A., Koptseva N.P., Libakova N.M., Luzan V.S., Sergeeva N.A., Sertakova E.A., 2016. Economic migration in Central Siberia and ethnic conflict risks (Based on Krasnoyarsk Krai Analysis). International Journal of Economics and Financial Issues 6: 104-108.

Krasnoshtanova N.E., 2019. New economic development of the North of Irkutsk Region: Socio-ecological consequences. IOP Conference Series: Earth and Environmental Science. 381: 012048. DOI 10.1088/1755-1315/381/1/012048

Laruelle M., 2016. New mobilities and social changes in Russia's Arctic regions. Routledge, London.
Li X., Huang S., Chen J., Chen Q., 2020. Analysis of the driving factors of U.S. domestic population mobility. Physica A: Statistical Mechanics and its Applications. 539: 122984 DOI 10.1016/j.physa.2019.122984

Masyagina O.V., Menyailo O.V., 2020. The impact of permafrost on carbon dioxide and methane fluxes in Siberia: A meta-analysis. Environmental Research. 182: 109096. DOI 10.1016/j.envres.2019.109096

McLeman R., Gemenne F. (Eds.), 2018. Routledge handbook of environmental displacement and migration. Routledge, London.

Molloy R., Smith C.L., Wozniak A., 2011. Internal migration in the United States. Journal of Economic Perspectives 25: 173-196. DOI 10.1257/jep.25.3.173

Mueller L., Sheudshen A.K., Syso A., Barsukov P., Smolentseva E.N., Khodzher T., Sychev V.G., Romanenkov V.A., Rukhovich O.V., Puzanov A., Dannowski R., Schindler U., Eulenstein F., 2016. Land and water resources of Siberia, their functioning and ecological state. In: Mueller L., Sheudshen A.K., Eulenstein F. (eds), Novel methods for monitoring and managing land and water resources in Siberia. Springer Water. Springer International Publishing, Cham: 3-73. DOI 10.1007/978-3-319-24409-9_1

Nemeryuk E., Anikin L., 2014. Teoreticheskiye podkhody k issledovaniyu prichin migratsii (Theoretical approaches to research of migration causes). Izvestiya of Saratov University. New series. Series Sociology. Politology 14: 23-28.

Partridge M.D., 2010. The duelling models: NEG vs amenity migration in explaining US engines of growth. $\mathrm{Pa}$ pers in Regional Science 89: 513-536. DOI 10.1111/j.14355957.2010.00315.x

Piguet E., 2010. Linking climate change, environmental degradation and migration: A methodological overview. Wiley Interdisciplinary Reviews: Climate Change 1(4): 517524. DOI 10.1002/wcc.54

Piguet E., 2013. From "primitive migration" to "climate refugees": The curious fate of the natural environment in migration studies. Annals of the Association of American Geographers 103(1): 148-162. DOI 10.1080/00045608.2012.696233

Piguet E., Pécoud A., De Guchteneire P., 2011. Migration and climate change: An overview. Refugee Survey Quarterly 30(3): 1-23. DOI 10.1093/rsq/hdr006

Ponomarev E., Kharuk V., Ranson K., 2016. Wildfires dynamics in Siberian larch forests. Forests 7(6): 125. DOI 10.3390/f7060125

Popod'ko, G.I., 2017. Puti preodoleniya neravenstva sotsial'no-ekonomicheskogo razvitiya otstalykh regionov (na primere Respubliki Tyva) (Ways to overcome the inequalities of socio-economic development of backward regions: Evidence from the Republic of Tyva). Regional Economics: Theory and Practice 15(2): 315-328. DOI 10.24891/ re.15.2.315

Poston D.L. Jr., Zhang L., 2008. Ecological analyses of permanent and temporary migration streams in China in the 1990s. Population Research and Policy Review 27: 689-712. DOI 10.1007/s11113-008-9094-5

Poston D.L., Frisbie W.P., 2005. Ecological demography. In: Poston, D.L., Micklin, M. (eds), Handbook of population, handbooks of sociology and social research. Springer US, Boston: 601-623. doi: 10.1007/0-387-23106-4_21

Poston D.L., Zhang L., Gotcher D.J., Gu Y., 2009. The effect of climate on migration: United States, 1995-2000. Social Science Research 38: 743-753. DOI 10.1016/j.ssresearch.2008.10.003 
Prokhorov P.E., Epstein N.D., 2016. Statisticheskiy analiz migratsionnoy situatsii i faktorov, vliyayushchikh na demograficheskuyu ekspansiyu Rossii (Statistical analysis of the migration situation and the factors affecting the Russian demographic expansion). Statistics for Economics 6: 9-18. DOI 10.21686/2500-3925-2016-6-9-18

Rajbhandari I., Partridge M., 2018. State of the art and future challenges of interregional migration empirical research in North America. In: Biagi B., Faggian A., Rajbhandari I., Venhorst V. (eds), New frontiers in interregional migration research. Advances in spatial science (The Regional Science Series). Springer, Cham: 63-86. DOI 10.1007/978-3-31975886-2_4

Regions of Russia. Socio-economic indicators, 2020. Rosstat Russian State Statistics Agency. Online: gks.ru/folder/210/ document/13204 (accessed 10 April 2020).

Russian Federal Service for Hydrometeorology and Environmental Monitoring, 2019. Doklad ob osobennostyakh klimata na territorii Rossiyskoy Federatsii za 2018 god (Report on climate features on the territory of the Russian Federation in 2018). Roshydromet, Moscow. Online: meteorf.ru/upload/pdf_download/o-klimate-rf-2018.pdf (accessed 24 May 2020)

Shakhova N., Semiletov I., Chuvilin E., 2019. Understanding the permafrost-hydrate system and associated methane releases in the East Siberian arctic shelf. Geosciences 9: 251. DOI 10.3390/geosciences 9060251

Shiklomanov N.I., Streletskiy D.A., Grebenets V.I., Suter L., 2017. Conquering the permafrost: Urban infrastructure development in Norilsk, Russia. Polar Geography 40: 273290. DOI 10.1080/1088937X.2017.1329237

Soboleva V.N., Melnikov S.M., 1999. Migracionnye processy v Magadanskoj oblasti (Migration processes in Magadan Region). Sotsiologicheskie issledovaniya. 11: 58-62.
Taskayeva S., 2007. Faktory, opredelyayushchiye migratsiyu naseleniya (The factors determining people migration). Transbaikal State University Journal 3: 174-179.

Tchebakova N.M., Parfenova E.I., Lysanova G.I., Soja A.J., 2011. Agroclimatic potential across central Siberia in an altered twenty-first century. Environmental Research Letters. 6: 045207. DOI 10.1088/1748-9326/6/4/045207

Tikhomirov N.P., Tikhomirova T.M., 2020. Metody obosnovaniya strategiy preodoleniya demograficheskogo krizisa v regionakh Rossii (Methods of justification for strategies to overcoming demographic crisis in the regions of Russia). Fundamental Research 5: 160-166. DOI 10.17513/ fr. 42764

Tsoy Y. 2019. O nekotorykh migratsionnykh protsessakh perekhodnogo perioda v Respublike Krym (About some migration processes of the transition period in the Republic of Crimea). Articles of the X All-Russian Scientific and Practical Conference "State, Government And Law", 287-289. Online: iguip.narod.ru/life/Sbornik_konferencii_GVUP_GUU_2019.pdf\#page=288 (accessed 27 May 2020)

Ullman E.L., 1954. Amenities as a factor in regional growth. Geographical Review. 44: 119-132. DOI 10.2307/211789

Vasilev A., 2019. Part of the residents of Tulun affected by the flood intends to move to Bratsk. Portal Gorod Online: tkgorod.ru/news/18704 (accessed 19 April 2020).

Weather forecasts and observational data, 2020. Raspisaniye Pogodi Ltd. Online: rp5.ru/docs/about/en (accessed 27 April 2020).

Zamyatina N., 2017. Migration destination choice as a criterion of self-identification. Sibirica 16(3): 57-76. DOI 10.3167/sib.2017.160304 